\title{
EDITORIAL
}

\section{LEGAL REFORM DISCOURSE IN INDONESIA AND GLOBAL CONTEXT: HOW DOES THE LAW RESPOND TO CRIME}

\author{
Ridwan Arifin ${ }^{\Perp}$ \\ ${ }^{1}$ Universitas Negeri Semarang, Managing Editor Journal of Law and Legal Reform \\ $\bowtie$ ridwan.arifin@mail.unnes.ac.id
}

Law is considered as a rule that applies in society, both traditional and modern societies. Naturally the calm and serenity of life is achieved if the community provides control, social supervision, both written and unwritten. Realistically these elements of social oversight will experience changes and developments both in evolution and revolution in accordance with the development of society. Implementation of regulations is a manifestation of the desire of the rule of law so that the function of social control and social control can be embodied in society. Therefore, both the law and society must adjust to the development that occurs, so that harmony occurs between the two. This is as stated by Rosana (2013) and Utari \& Arifin (2019).

But the fact is, the development of law is not as fast as the development of society. In fact, the types of crime are growing, also various problems that arise in the community continue to develop. However, much we know a lot about the factors of crime that exist in society, but what is certain is that crime is a form of human behavior. Therefore, crime has been accepted as a fact, both in the simplest (primitive) society and in modern society, which harms society (Rahardjo, 2002). The more advanced and modern life of society, the more advanced and modern types and modus operandi of crimes that occur in society.

The inability of the law to respond to the rapid development of society raises its own problems. So that in many cases, legal uncertainty arises as a result of rigid laws. For example, a few years ago, Indonesia stuttered a little in the face of the rapid development of online transportation. On the one hand, people need various facilities and this is obtained from the phenomenon of online transportation, but on the other hand, this type of online transportation does not yet have a clear legal umbrella. Therefore, there are many conflicts and friction between users and providers of 
conventional transportation services with users and providers of online transportation services.

In fact, the law and the community are always side by side, ubi societas ibi ius, where there is a community there is a law. Some previous researches also emphasized that law and legal reform in various countries-including Indonesia-influenced by many factors (Rodiyah, Laskarwati, Masyhar, \& Waspiah, 2019; Suwandoko \& Rodiyah, 2018; Muhtada, 2017a, 2017b; Arifin, 2017). The second edition of the Journal of Law and Legal Reform presents writings from various perspectives within the framework of legal reform. The articles that are present to the reader in this edition are selected papers that have gone through a double-blind peer-reviewed process by expert reviewers. The articles discuss various aspects of legal reform in Indonesia and in the global context.

Anang Wahyu Kurnianto and Ridwanto Ardi Kusumo, provided special notes on the mechanism of inter-time elections (Recall) in the Election of Regional Heads in the context of Democracy in Indonesia and reform of the electoral law. Meanwhile, Idul Hanzah Alid and Lailasari Ekaningsih analyzed the government's efforts to protect intellectual property rights (trade secrets) in Indonesia. This paper takes one of the companies in Central Java and concludes that a written agreement is needed as a clear legal basis for protecting trade secrets (Kurnianto \& Kusumo, 2020; Alid \& Ekaningsih. 2020)

Another article was written by Sinta Oktavina regarding government policies in engineering population growth through family planning. Novi Anggraini Putri highlights the child sexual abuse cases, and she analyzes case related to military member (Oktavina, 2020; Putri, 2020). and various other writings from other fields of law, such as criminal law, child protection, and state administration.

In this second edition, we present thirteen writings (Research and Review Articles) and one Current Commentary. We thank all the authors, contributors, and also Reviewers who were involved directly or indirectly in the preparation and publication of this second edition. In addition, our gratitude also goes to the Indonesian Legal Journal Management Association (APJHI) for all its support, and the Law Masters Study Program at the Faculty of Law, Semarang State University.

I personally thank Dr. Rodiyah SPd SH MSi (Dean of the Faculty of Law), Dr. Indah Sri Utari SH MHum (Chair of the Master of Laws Program), and the entire Team of the Journal of Law and Legal Reform. This year, the Journal of Law and Legal Reform continues to improve the quality of journal content and online journal page display with several national and international indexations.

Starting this year, we have explored cooperation with several agencies in improving the quality of journals, among the General Election Supervision Board, several Law 
Firms, Government Agencies, and several Non-Governmental Organizations in participating in providing input and suggestions for the future development of our journal. We also provide wide opportunities for anyone who has an interest in our journal. We hope that, through the publication of this second edition of the journal, it will be able to contribute to legal scholarship and discourse on the development of law in Indonesia in a global context.

\section{REFERENCES}

Alid, I. H., \& Ekaningsih, L. (2020). How Government Provide Legal Protection for Trade Secrets?. Journal of Law and Legal Reform,1(2), 215-224. https://doi.org/10.15294/jllr.vli2.35420

Arifin, R. (2017). Democracy on Indonesian Legal Reform: How Can People Participate on Laws and Regulations Establishment Process. JILS (Journal of Indonesian Legal Studies), 2(02), 155-158. https://doi.org/10.15294/jils.v2i02.19439

Kurnianto, A. W., \& Kusumo, R. A. (2020). Recall on Village Heads Election: An Election Law Reform. Journal of Law and Legal Reform, 1(2), 201-214. https://doi.org/10.15294/jllr.vli2.35406

Muhtada, D. (2017a). The Prospects for Public Management Reform in Indonesia. JILS (Journal of Indonesian Legal Studies), 2(02), 145-154. https://doi.org/10.15294/jils.v2i02.19437

Muhtada, D. (2017b). Legal Reform in Indonesia. JILS (Journal of Indonesian Legal Studies), 2(02), 83-84. https://doi.org/10.15294/jils.v2i02.19438

Oktavina, S. (2020). Population Growth Control Policy and Its Effect to Law Enforcement. Journal of Law and Legal Reform,1(2), 225-240. https://doi.org/10.15294/jllr.vli2.35460

Putri, N. A. (2020). Judgment Considerations Regarding Decisions about Child Sex Abuse Crime Conducted by Military Member. Journal of Law and Legal Reform, 1(2), 24l-258. https://doi.org/10.15294/jllr.vli2.35421

Rodiyah, R., Laskarwati, B., Masyhar, A., \& Waspiah, W. (2019). How Should Student Behave? A Legal Ethics and Policy towards Nationalism and AntiRadicalism Characters. JILS (Journal of Indonesian Legal Studies), 4(2). https://doi.org/10.15294/jils.v4i2.34343

Rosana, E. (2013). Hukum dan Perkembangan Masyarakat. Jurnal Teropong Aspirasi Politik Islam, 9(1), 99-118. DOI: https://doi.org/10.24042/tps.v9il.1578

Suwandoko, S., \& Rodiyah, R. (2018). The Implementation of Bureaucratic Reform Pillars in Increasing Taxpayer Compliance at Semarang Tax Service Office. JILS (Journal of Indonesian Legal Studies),3(01), 5-28. https://doi.org/10.15294/jils.v3i01.23244

Utari, I. S., \& Arifin, R. (2019). Law Enforcement and Legal Reform in Indonesia and Global Context: How the Law Responds to Community Development?. Journal of Law and Legal Reform, 1(1), 1-4. 


\section{QUOTE}

Most of the time, when one analyzes the role of the state in our society, either one focuses attention on institutions - armies, civil service, bureaucracy, and so on-and on the kind of people who rule them, or one analyzes the theories or the ideologies which were developed in order to justify the existence of the state.

What I am looking for, on the contrary, are the techniques, the practices, which give a concrete form to [the] ... relationship between the social entity and the individual.

Michel Foucault, "The Political Technology of Individuals" (1981) 